\title{
Effects of Petroleum and Crude Oil in the Gastrointestinal System of Male Roadside Mechanics in Enugu State, Nigeria.
}

\author{
F. N Oguwike ${ }^{1}$, Ebede S. ${ }^{2}$, Onubeze D.P.M ${ }^{3}$, Offor C.C ${ }^{3}$. \\ ${ }^{I}$ Department of Human Physiology, Faculty Of Basic Medical Sciences, Anambra State University Uli, \\ Anambra State. \\ ${ }^{2}$ Department of Medical Microbiology, University of Nigeria Teaching Hospital Ituku Ozalla Enugu State \\ Nigeria. \\ ${ }^{3}$ Department of Community Medicine, Anambra State University Teaching Hospital Amaku Awka, Nigeria. \\ ${ }^{4}$ Department of Medical Biochemistry, Anambra State University Uli, Anambra State, Nigeria.
}

\begin{abstract}
The exposure of motor mechanics to petrol and crude oil products daily basis in the course of their job could be dangerous. Thirty adult males were used in this study. Their average weight is 70-75kg. they were grouped into two groups. Group X (15) are the control subjects and Group Y (15) are the test subjects. The test subjects were monitored on daily basis in the use of petrol in their daily job. At the end of 28 days, blood samples were collected from them and from the apparently healthy control subjects. Haematological tests carried out revealed decrease in haemoglobin concentration, packed cell volume and the biochemical indices did not reveal much effect in the liver function test. There was absence of streptococci pyogenes and candida alicaus in their oral cavity showing that their exposure to petrochemical products discorage the growth of bacteria in their oral cavity.

It coud be deduced from this study that daily exposure to petrol gradually causes reduction in blood levels and sterility of the oral cavity.
\end{abstract}

Key Words: Petrol, haemoglobin, liver function test, roadside mechanics, gastrointestinal system, bacteria.

\section{Introduction}

Petroleum also called crude oil is a liquid found within the Earth comprise of hydrocarbons, organic compounds and small amounts of metal.

Crude oil is created through the heating and compression of organic materials over a long period of time. Most of the oil extracted today comes from the remains of prehistoric algae and zooplankton whose remains settled on the bottom of an ocean or lake. Over time this organic material combined with mud and was then heated to high temperatures from the pressures created by heavy layers of sediment. This process known as diagenesis, changes the chemical composition first into a waxy compound called kerogen and then, with increased heat into a liquid through a process called catogenesis.

This petroleum is used as a fuel for driving for cars, buses, tricycles, motorcycles, and a host of other engines. It is the liquid or cleansing agent the autotechnicians (automechanics) in our coutry uses most of the time to wash their hands off grease and stains, wash motor engine parts, car plugs etc during their daily work.

Life enthusiasms and challenges to meet the day to day financial needs forced. Some of the young men into the job of roadside mechanic or auto technician work. They service and repair faulty cars, buses, tricycle (Keke napep) etc and put them back on the road again.

In the process of their job, most times they intensionally siphon petrol with their mouth, sucking auto engine fuel pipe and transferring it into car carburetors so as to ensure proper circulation of fuel in the faulty cay they are servicing in order to start the engine. When the petroleum products are mistakenly swallowed, they go into the gastrointestinal tract (GIT). It is also called the alimentary canal, the avenue through which nutritive substances, vitamins, minerals and fluids enter the body. Proteins, fats oils, and complex carbohydrates are broken down into absorbable units mainly in the small intestine. The products cross the mucosa and enter the lymph or the blood (Oguwike 2013). The gastrointestinal system is divided into five main parts mouth and pharynx, oesophagus, stomach, small intestine and large intestine (Osim 2002). Each segment or part is adapted for specific functions such as oesophagus is for simple passage of food in the body of the stomach while the large intestine and the small intestine and the proximal half of the colon is for absorption of the digested end products.

The effect of this petrol in their gastrointestinal tract and other blood parameters, the safe use of this products are ehat prompted my curiosity to engage in this research. Most of those roadside mechanics are not enlightened and day by day they are engaged in this routine job in order to survive. Crude oil is pumped from the ground in the Middle east (eg Saudi Arabian Arab Light), West Africa, (eg Nigerian Bonny Light), the Americans and Asia (Russia), pumped into ships called tankers and sailed across the ocean to oil refineries on 
the Delaware River. The top five oil producing countries are Saudi Arabia, Russia, United States, Iran and China. The Five top oil consuming countires are united States, China, Japan, Russia and Germany.

\section{Chemical Composition Of Petrol And Crude Oil:}

They are composed of hydrocarbons, organic compounds and small amounts of metal. While hydrocarbons are usually the primary components of crude oil, their composition can vary from $50 \%-97 \%$ depending on the type of crude oil and how it is extracted . organic compounds like nitrogen, oxygen and sulphur typically make up between $6 \%-10 \%$ of crude oil while metals such as copper, nickel, vanadium and iron account for less than $1 \%$ of the total composition.

There is no medical value of petrol or crude oil being used in treating diseases rather there are some unrecorded superstitials belief among the low income people that they use it to hasten labour and treat some stomach ailments.

\section{Material And Methods:}

The subjects in this study consist of two group which are the control group (X) 15 male and the chronic users of petrol products (roadside mechanics) Group Y consisting of 15 adult males.

\section{Experimental Design:}

30 adult male subjects of age range $25-50 \mathrm{yrs}$ were selected for this study. They weighed $60-75 \mathrm{~kg}$. The test group was monitored for one month to ensure their regular use of fuel in their routine work petrol was purchased at NNPC mega station at Enugu and was shared to the test group Y to assist them in the regular use for one month.

\section{Determination Of Biochemical, Bacteriological And Haematological Profile:}

Blood samples were collected into EDTA sequetrene bottles for the haematological studies, those collected in plain tubes were allowed to clot, later their serum samples were removed and placed in clean test tubes for biochemical tests. Swab sticks were used to collect throat and oral swab samples from the test groups and control groups for bacteriological studies.

Tests:

The haematological analysis: Haemoglobin (Hb), white blood cell (WBC), packed cell volume (PCV), platelet counts were carried out with the aid of an automatic haematology analyzer (Minray Haematology analyzer, (BC- 2300), while the biochemical analysis viz fasting blood sugar and liver function tests were carried out as described by Baker and Silverton (1985). Culture tests were performed using the swab samples and plating than on blood and Mackonkey agar. Also the baseline of Kass 1973 that any colony of bacteria up to $10^{3}$ is significant in any growth (Gilles 1973) Morphology colour, characteristic appearance of the colony were used to identifiy the growth (Baker 2007).

\section{Statistical Analisis:}

The results obtained in the study for bacteriological, biochemical and haematological profiles were represented as Mean and Standard deviation (Mean \pm S.D) while students' $T$ test was used to compare the result of the control and the test. A p-value of less than $(\mathrm{P}<0.05)$ or equivalent $(\mathrm{P}=0.05)$ was considered significant.

\section{Results}

Table 1: The effect of fuel on biochemical profile of adult male roadside mechanics.

\begin{tabular}{|l|l|l|l|l|l|l|}
\hline GROUPS & $\begin{array}{l}\text { FBS mg/dl } \pm \\
\text { S.D }\end{array}$ & $\begin{array}{l}\text { Total Bilirubin } \\
\mathrm{mg} / \mathrm{dl} \pm \text { S.D }\end{array}$ & $\begin{array}{l}\text { Conj Bilirubin } \\
\mathrm{mg} / \mathrm{dl} \pm \text { S.D }\end{array}$ & $\begin{array}{l}\text { Alkaline Phos } \\
\mathrm{m} / \mathrm{l} \pm \mathrm{S} . \mathrm{D}\end{array}$ & $\begin{array}{l}\text { AST m/l } \pm \\
\text { S.D }\end{array}$ & $\begin{array}{l}\text { ALT m/l } \pm \\
\text { S.D }\end{array}$ \\
\hline Control (n=15) Group X & $74 \pm 0.82$ & $3.0 \pm 0.16$ & $0.5 \pm 0.1$ & $72 \pm 5.0$ & $9.0 \pm 3.0$ & $8.6 \pm 3.2$ \\
\hline $\begin{array}{l}\text { Test Groups before fuel } \\
\text { usage Group Y n=15 }\end{array}$ & $78 \pm 1.4$ & $3.2 \pm 0.18$ & $0.4 \pm 0.1$ & $74 \pm 12$ & $10.4 \pm 2.6$ & $9.4 \pm 2.4$ \\
\hline $\begin{array}{l}\text { Test Groups (Y) 30 days } \\
\text { after fuel usage. }\end{array}$ & $76 \pm 0.6$ & $1.6 \pm 0.2$ & $0.2 \pm 0.1$ & $40 \pm 3.0$ & $4.2 \pm 0.6$ & $4.2 \pm 0.4$ \\
\hline P-value & $\mathrm{P}>0.05$ & $\mathrm{P}>0.05$ & $\mathrm{P}>0.05$ & $\mathrm{P}>0.05$ & $\mathrm{P}>0.05$ & $\mathrm{P}>0.05$ \\
\hline
\end{tabular}

Table 2: The effect of fuel in the bacteria colony in the throat and oral cavity of adult male roadside mechanics.

\begin{tabular}{|l|l|l|l|l|}
\hline \multicolumn{4}{|l|}{ Presence or Absence } & Candida \\
\hline Groups & E. coli & Staph aureus & Strep pyogene & - \\
\hline Control n=15 (Group X) & - & - & + & - \\
\hline $\begin{array}{l}\text { Test Group Y before fuel usage Group } \\
\text { Y n=15 }\end{array}$ & - & + & + & - \\
\hline Test Groups 30 days after fuel usage. & - & - & - & P \\
\hline P-value & $\mathrm{P}>0.05$ & $\mathrm{P}<0.05$ & $\mathrm{P}<0.05$ & $\mathrm{P}>0.05$ \\
\hline
\end{tabular}


Table 3: The effect of fuel on the haematological profile of adult malen roadside mechanics.

\begin{tabular}{|l|l|l|l|l|}
\hline GROUPS & $\mathrm{Hbg} / 100 \mathrm{ml} \pm$ S.D & $\mathrm{PCV} \% \pm$ S.D & $\begin{array}{l}\mathrm{WBC} / \mathrm{mm}^{3} \\
\text { S.D }\end{array}$ & $\begin{array}{l}\text { Platelet } \mathrm{x} 10^{9} / 1 \\
\pm \text { S.D }\end{array}$ \\
\hline Control n=15 Group X & $15.5 \pm 1.36$ & $46.5 \pm 4.08$ & $6,840 \pm 3.2$ & $220 \pm 74$ \\
\hline $\begin{array}{l}\text { Test Groups before fuel usage } \\
\text { Group n=15 }\end{array}$ & $15.2 \pm 0.82$ & $45.6 \pm 2.46$ & $7,220 \pm 606$ & $218 \pm 65$ \\
\hline Test Group 30 days after fuel usage & $9.28 \pm 1.24$ & $27.74 \pm 3.52$ & $3,412 \pm 56$ & $170 \pm 49$ \\
\hline P-value & $\mathrm{P}<0.05$ & $\mathrm{P}<0.05$ & $\mathrm{P}<0.05$ & $\mathrm{P}<0.05$ \\
\hline
\end{tabular}

\section{Discussion}

The effect of Petroleum and Crude oil in the gastrointestinal system of Roadside mechanincs in Enugu Nigeria have been studied. The study observed some alterations in the bacteriological and haematological profile but not much differences in the biochemical indices.

The haemoglobin concentration and packed cell volume was significantly reduced in the Roadside mechanics compared with their corresponding control (Group X) who do not engage in the work.

The result obtained showed that group $\mathrm{X}$ have their haemoglobin concentration and packed cell volume $40 \%$ lower than their control subjects (Table 3). Haemoglobin concentration in control subjects (X) was obtained as $15.5 \mathrm{~g} / 100 \mathrm{ml}$ compared to the test subjects $9.28 \pm 1.24 \mathrm{~g} / 100 \mathrm{ml}$. The Packed cell volume was also reduced giving the values of $46.5 \pm 408$ in the control subjects and $27.74 \pm 35.2 \mathrm{~L} / \mathrm{L}$ in the subjects reduced. Most constituents of petroleum and crude oil are highly toxic to biological membranes and proteins, naphthalene for example has been reported to cause haemoglobin denaturation and is one of the compound groups responsible for the development of haemolytic anaemia in oiled wild life (Debra, 2003). The presence of this toxic constituent may possibly explain the low values of haemotological parameters (Ita et al, 2011) recorded in the research. It also amongst other toxicants, suppresses the immune system causing disruption or suspension of haematopoiesis (Hodgson and Smart, 2001) which collaborate the results in this study (Table 3). It has also been established that the toxic constituents of petroleum such as benzene and lead are activated in the bone marrow, where these could be mediated through disturbances in DNA function (Okoro et al, 2006). The resultant bone marrow depression is characterized by inadequate production of red cell and other formed elements. The mean platelet count and WBC were slightly lower through within the normal range in the test subjects.

The study of the biochemical parameters (Table 1) such as Fasting blood sugar (FBS) and Liver Function Test (LFT) in the subjects exposed to petroleum products showed no significant value when compared to the control subjects.

This could give rise to safe manipulation of petrol by the subjects as long $\mathrm{s}$ the toxic contents do not damage the liver and pancreas. The study on the effect of the petrol in the oral cavity of the test subjects showed absence of streptococcus pyogenes and candida albicans compared to the control subjects (Table 2).

The sterility of the oral cavity could be due the presence of hydrocarbon in petrol which discourages the growth of bacteria in the oral cavitry of test subjects.

\section{References}

[1]. $\quad$ BAKER F.J, SILVERTON (1998). "Plate cultural methods. Introduction to Medical Laboratory Technology $7^{\text {th }}$ Edition pg 276. Butterworth- Heinemann publication. Linacre House, Jordan Hill, Oxford OX28DP. 225 Wildwood Avenues, Woburn MA 01801 2041.

[2]. DEBRA B.M (2003). The rapentic and toxicity information of crude oil. J. Nutri 68: 297-400.

[3]. GILLIES R.R (1973). Urinary tract infection Medical Microbiology, Twelfth Edition value 1, Microbiology infections 329-332.

[4]. HODGSON E and SMART R.C (2001). Introduction to Biochemical Toxicology, $3^{\text {rd }}$ Edn, Wiley New York pp 199-220.

[5]. ITA S.O and UDOFIA U.A (2011). Comparative studies of some haematological parameters in Rats following Ingestion of Crude oil (Nigerian Bonny Light),, Petrol, Kerosene and Diesel. Asian Journal of Biological Sciences 4: 498-505.

[6]. OGUWIKE F.N 2013. Gastrointestinal physiology, Comparative Medical Physiology pg 71. Published in Nigeria by Idealway Publications Nig. 39 Nike Road Enugu, Enugu State.

[7]. OKORO A.M, ANI E.J, IBU J.O, AKPOGOMEH B.A (2006). Effect of Petroleum products inhalation on some haematological indices of fuel attendants in Calabar metropolis, Nigeira. Nig. J physiol Sci 21: 11-75.

[8]. OSIM E.E (2002). "Physiological anatomy of the digestive tract". Elements of Gastrointestinal tract physiology pg 2. Pulished by Helimo Associates, 4 Fenton street Calabar Nigeria. 